ACTA AGROBOTANICA

Vol. 58, z. 2 - 2005

s. $19-32$

\title{
Use of molecular and conventional techniques to identify and analyze genetic variability of Rhizoctonia spp. isolates
}

\section{LIDIA IRZYKOWSKA ${ }^{1}$, EWA ŻÓŁTAŃSKA ${ }^{1}$, JAN BOCIANOWSKI ${ }^{2}$}

\author{
${ }^{1}$ Katedra Fitopatologii, Akademia Rolnicza w Poznaniu, \\ ul. Dąbrowskiego 159, 60-594 Poznań \\ ${ }^{2}$ Katedra Metod Matematycznych i Statystycznych, Akademia Rolnicza w Poznaniu, \\ ul. Wojska Polskiego 28, 60-637 Poznań \\ ${ }^{1}$ Department of Phytopathology, The University of Agriculture, \\ Dąbrowskiego 159, 60-594 Poznań, Poland \\ ${ }^{2}$ Department of Mathematical and Statistical Methods, The University of Agriculture, \\ Wojska Polskiego 28, 60-637 Poznań, Poland \\ *Corresponding author, e-mail: irzyk@au.poznan.pl fax: 48618487999
}

(Received: 21.03.2005)

\section{Summary}

In this study the pathogenicity of Rhizoctonia spp. isolates towards wheat seedlings in laboratory and greenhouse conditions was evaluated. In both experiments seven features were examined: plant height, roots weight, the percentage of infected stems and leaf sheaths and also the degree of stem and leaf sheaths infection. Isolates R1, R29, R39 and R59 were the most pathogenic. Percentage of infected stems ranged from 25.3 to 82.5 and roots from 35 to 82.3 . The amplification of internal transcribed spacer regions (ITS1 and ITS2) between 18S, 5.8S and 28S rRNA genes and sequence analysis of these regions have been shown to be sufficiently variable to resolve two Rhizoctonia species. Random amplified polymorphic DNA (RAPD) was used to assess genetic variability among isolates. The suitability of RAPD method for isolates differentiation at intraspecific level was shown. Using seven arbitrary primers in polymerase chain reaction (PCR) thirty-three RAPD markers were generated. Clustering analysis from RAPD data resolved two groups of $R$. cerealis isolates at the $36 \%$ similarity level. Moreover, significant associations between molecular markers and pathogenicity of $R$. cerealis isolates were found.

Key words: ITS, pathogenicity, RAPD, Rhizoctonia cerealis, Rhizoctonia solani 


\section{INTRODUCTION}

Fungi of the genus Rhizoctonia are commonly found on wheat in various regions where this crop is cultivated. Symptoms caused by these pathogens are diverse and include preemergence damping-off, root rot, foliar blight, hypocotyl rot and sheath blight (M a z z o la et al., 1996). Causal agents of sharp eyspot on wheat have been reported as Rhizoctonia cerealis (teleomorph: Ceratobasidium cereale) in Ohio (L i p p and H e r r , 1982) and in Europe (P i t t, 1964, H o 11 in s et al., 1985). However, R. solani AG4 as well as $R$. cerealis were reported to cause sharp eyspot on rye (V a n d e r H o e v e $\mathrm{n}$ and B o 11 e n, 1980). Sharp eyspot is characterized by development of elliptical lesions on the leaf sheath near the base of wheat and barley culms.

Traditional identification of the Rhizoctonia species is time-consuming and requires special staining procedures to assess the nuclear condition of the hyphal cells. The mycelial cells of $R$. solani contain an indefinite number of nuclei (multi-nucleate) while those of $R$. cerealis have two nuclei per cell. Classical diagnostic methods are laborious and need specialistic approach to obtain well growing pure cultures.

One of the difficulties in using morphological and physiological traits in diagnostics is that significant variation can occur among isolates of the same species under varying environmental conditions (i.e. temperature, humidity, $\mathrm{pH}$, chemical compounds of medium etc.), interaction with host plant and developmental stage of the pathogen. An additional problem is that many species never undergo sexual reproduction or it is difficult to obtain in laboratory conditions, which significantly limits the available morphological traits set. Molecular markers application allows avoiding most doubts, which appear during research based on classical methods. Molecular markers are independent of environmental conditions, nutrient medium etc., which makes them more useful and universal than morphological features.

From among currently known marker systems, most is based on polymerase chain reaction (PCR). Random amplified polymorphic DNA (RAPD) technique has been applied to a wide range of organisms providing a suitable tool for detection of intra- or interspecies variations (C o o k et al., 1996). For cereal pathogenic fungi, RAPD technique has been used to analyse genetic variation of Rhizoctonia cerealis $(\mathrm{N}$ i chol- s o n and Parry, 1996), Gaeumannomyces-Phialophora complex (Augustin et al., 1999) and Drechslera teres (P e 1 t o n e n et al., 1996). Ribosomal DNA (rDNA) genes are widely used for fungal molecular taxonomy (C $\mathrm{r}$ a w for $\mathrm{d}$ et al., 1996). As they are highly conserved, the rDNA sequences can discriminate at the levels of orders. For phylogeny studies at the species level the noncoding internal transcribed spacers (ITS) are used.

The aims of this study was to evaluate pathogenicity of Rhizoctonia sp. towards wheat seedling in the laboratory and greenhouse conditions, identify a species using molecular methods and find molecular markers associated with phenotypic features examined. 


\section{MATERIAL AND METHODS}

\section{Fungal isolates and phenotypic features}

Eleven isolates of fungi (R1, R8, R11, R24, R29, R39, R40, R42, R45, R47, R59) belonging to the Rhizoctonia genus were obtained from stems of winter wheat planted using conventional cultivation practices. Pathogenicity of the isolates was investigated in a laboratory experiment on Petri dishes and in a greenhouse experiment. The investigations were done on 2 cultivars of wheat: Almari (winter wheat) and Eta (spring wheat). The filter paper soaked in distilled water was placed on Petri dishes and next pieces of PDA overgrown with the isolates of the fungus examined were placed on top in the laboratory experiment. Ten seeds were placed on each dish. After one week the percentage of infected stems and roots and degree of infection on a scale 1-3: $1^{\circ}-<26 \%$ of the surface around the stem, $2^{\circ}-26-50 \%, 3^{\circ}->50 \%$ of the surface around the stem were assessed in four replications. In the greenhouse conditions six seeds of wheat were placed in pots $10 \mathrm{~cm}$ in diameter with steamed soil. A piece of PDA overgrown with the isolates of fungus under investigation was placed under each seed. After 1 month the effect of the isolates on the growth and health of plants was examined. The following characteristics were assayed: plant height (after 2 weeks), roots weight, the percentage of infected stems and leaf sheaths and the degree of stem and leaf sheaths infection on the described above 3 -grade scale. The greenhouse investigations were conducted in five replications.

\section{DNA preparations and RAPD assays}

Mycelia from 7-days cultures grown on liquid medium (5 gl-1 of glucose, 1 gl-1 of yeast extract) were collected by vacuum filtration. DNA was extracted and purified using DNeasy Mini Kit (QIAGEN) according to the manufacturer's recommendations with slight modification. The isolate $R$. solani AG8 was used as a reference.

The RAPD-PCR reactions were carried out using Taq PCR Core Kit (QIAGEN) in a total volume of $4.5 \mu \mathrm{l}$. The reaction assay contained $3 \mathrm{ng}$ of fungal DNA, $200 \mu \mathrm{M}$ of each dNTP, $1 \mu \mathrm{M}$ primer and $0.5 \mathrm{U}$ of Taq DNA polymerase in 1x reaction buffer with $1.5 \mathrm{mM}$ magnesium chloride. Seven random 10-mer primers: C1503, C1504 (Promega), OPC05, OPJ04, OPJ05, OPJ14, OPJ18 (Operon) were used to screen the isolates for polymorphism. Amplification was carried out according to the following program: an initial denaturation for $2 \mathrm{~min}$ at $94^{\circ} \mathrm{C}$ followed by 50 cycles of denaturation at $94^{\circ} \mathrm{C}$ for $30 \mathrm{~s}$, primer annealing at $36^{\circ} \mathrm{C}$ for $1 \mathrm{~min}$ and extension at $72{ }^{\circ} \mathrm{C}$ for 2 min. The amplification was ended with additional extension at $72^{\circ} \mathrm{C}$ for $5 \mathrm{~min}$. PCR was repeated twice to check their reproducibility. A Gene Ruler ${ }^{\mathrm{TM}} 100 \mathrm{bp}$ DNA Ladder Plus (Fermentas) was used as a molecular size standard for RAPD markers.

\section{PCR amplification and sequencing of ITS1 and ITS2 regions of $r D N A$}

For ITS amplification and sequencing forward primer WIRZ-G1 (5'-GTAACAAGGTTTCCGTAGGTG-3') based on the Leptosphaeria maculans Leroy 18S rRNA 
gene (Irzykowski et al., 2004) and reverse primer PN10 (5'-TCCGCTTATTGATATGCTTAAG-3') based on Saccharomyces cerevisiae 28S rRNA gene (B a l e s $\mathrm{den} \mathrm{t}$ et al., 1998) were used. The $5 \mu \mathrm{l}$ reaction mixture contained $3 \mathrm{ng}$ of template DNA, $2 \mu \mathrm{M}$ of each primer, $200 \mu \mathrm{M}$ of each dNTP and $0.5 \mathrm{U}$ of Taq Polymerase (QIAGEN) in $1 \mathrm{x}$ reaction buffer. The PCR was performed for 50 cycles of denaturation at $94{ }^{\circ} \mathrm{C}$ for $30 \mathrm{~s}$, annealing at $60^{\circ} \mathrm{C}$ for $1 \mathrm{~min}$ and extension at $72^{\circ} \mathrm{C}$ for $1 \mathrm{~min}$, with initial denaturation of $2 \mathrm{~min}$ at $94^{\circ} \mathrm{C}$ before cycling and final extension of $5 \mathrm{~min}$ at $72{ }^{\circ} \mathrm{C}$ after cycling. A portion of the amplified products was electrophoresed. The remaining part of the PCR product was purified as described at http://genome.wustl. edu/gsc/Protocols/EXOSAP.shtml. Purified PCR products were fluorescently labelled with Big Dye ${ }^{\circledR}$ Terminator v 3.0 Cycle Sequencing Ready Reaction Kit with AmpliTaq DNA Polymerase, FS. (Applied Biosystems). Each DNA template was labelled using WIRZ-G1 and PN10 primers separately to obtain sequence from both strands. Sequencing was conducted on an ABI PRISM ${ }^{\circledR} 310$ Genetic Analyser. The resulting sequences were checked visually and were aligned using computer software package, Clustal X 1.81 (Th o m p s o n et al., 1997). Sequences were compared to GenBank+EMBL+DDBJ+PDB Sequence Database using computer software BLASTN 2.2.5 (Altschul et al., 1997).

\section{The electrophoresis conditions}

The RAPD and ITS amplification products were separated by electrophoresis in $1.5 \%$ agarose gel with $1 \times$ TBE buffer and visualised under UV light following ethidium bromide staining.

\section{Statistical analysis}

The analysis of variance for statistical verification of significant differences between the analyzed isolates for examined traits was made. The relationship between traits was calculated using correlation coefficient. The data of analyzed traits were used for testing differences of phenotypic means for groups of considered isolates with and without DNA amplification product for each primer, and each primer's amplification product (S olle r et al., 1976).

The coefficients of genetic similarity (GS) of the investigated isolates were calculated using the following formula ( $\mathrm{Nei}$ and $\mathrm{Li}, 1979)$ ): $\mathrm{GS}_{\mathrm{ij}}=2 \mathrm{~N}_{\mathrm{ij}} /\left(\mathrm{N}_{\mathrm{i}}+\mathrm{N}_{\mathrm{j}}\right)$, where $\mathrm{N}_{\mathrm{ij}}$ is the number of alleles present at $i$-th and $j$-th isolates, $\mathrm{N}_{\mathrm{i}}$ - the number of alleles present at the $i$-th isolate, $\mathrm{N}_{\mathrm{j}}$ - the number of alleles present at the $j$-th isolate, $i, j=$ $1,2, \ldots, 11$. The coefficients were used to group the isolates hierarchically using the unweighted pair group method of arithmetic means (UPGMA). Mahalanobis distance (i. e. distance between isolates evaluated for all studied traits treated simultaneously) was used as a measure of phenotypic similarity between studied isolates $(\mathrm{Ca}$ li ń s k i, 1970; M ardia et al. 1979). Correlation coefficient was estimated between genetic and phenotypic similarities. 


\section{RESULTS}

\section{Molecular identification}

The analysis of the internal transcribed spacer (ITS-1 and ITS-2) size polymorphism allowed distinguishing 11 isolates examined from reference isolate $R$. solani anasthomosis group 8 (Figure 1). The length of PCR products was further confirmed by ITS sequencing. Some diversity was found in ITS fragment. In most isolates ( 8 of 11 investigated) two sequences were found. Two size classes of PCR-ITS products were distinguished: 692/691 bp for 11 isolates examined and 682/681bp for $R$. solani AG8. Sequence of ITS region excluded entirely the possibility that 11 isolates examined belong to $R$. solani. ITS sequences of 11 isolates examined were quite similar to that of $R$. cerealis found in Genbank.

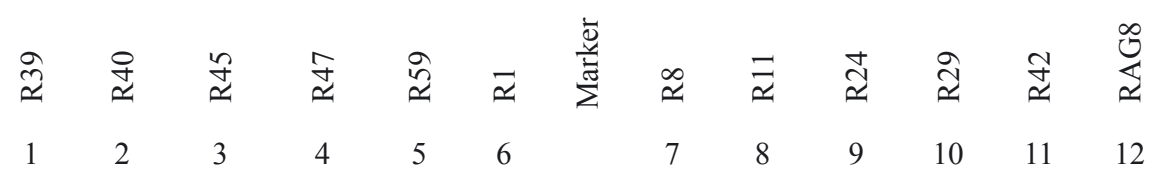

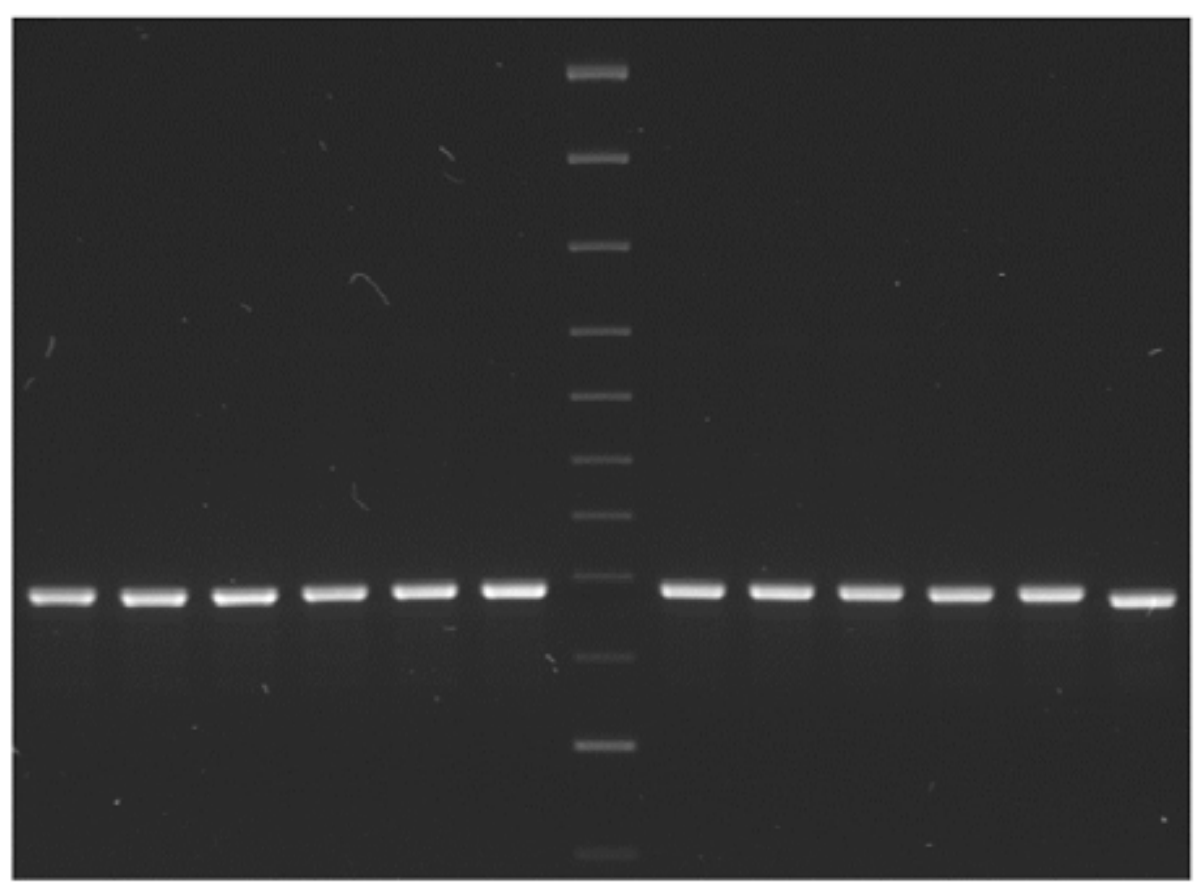

Figure 1. Banding patterns of Rhizoctonia isolates following ITS-PCR. A Gene Ruler ${ }^{\text {TM }} 100 \mathrm{bp}$ DNA Ladder Plus (Fermentas) was used as a molecular size standard for ITS fragments $(\mathrm{M})$ 


\section{Phenotypic features}

The analysis of variance shows that isolates differed with regard to percentage of infected stems and degree of stem infection in the case of both cultivars (Almari and Eta) and also percentage of infected roots of Eta and roots weight of Almari (Table 2 and 3). Percentage of infected stems ranged from 25.3 to 32.5 for Almari and from 37.5 to 82.5 for Eta. The degree of stem infection differed from 1.8 to 2.7 and from 2.3 to 2.8 for Almari and Eta respectively. The great percentage of infected roots was observed in the case of some isolates for the Eta cultivar. Mean values of examined features were shown in Table 1. Analysis of correlation was made jointly for features from greenhouse and laboratory experiments, which were carried out simultaneously. Correlation coefficient values were presented in Table 4. Phenotypic similarity was calculated on the basis of Mahalonobis distance for seven traits. The highest phenotypic similarity was revealed between the isolates R1 and R42, whereas the lowest phenotypic similarity was found for R8 and R45.

Table 1

Mean values for seven traits examined on Almari and Eta cultivars

\begin{tabular}{|c|c|c|c|c|c|c|c|c|c|c|c|c|c|c|}
\hline \multirow{3}{*}{ Isolates } & \multicolumn{14}{|c|}{ Traits examined } \\
\hline & \multicolumn{2}{|c|}{$\begin{array}{l}\text { Percentage } \\
\text { of infected } \\
\text { stems }\end{array}$} & \multicolumn{2}{|c|}{$\begin{array}{c}\text { Degree of } \\
\text { stem } \\
\text { infected }\end{array}$} & \multicolumn{2}{|c|}{$\begin{array}{c}\text { Percentage } \\
\text { of infected } \\
\text { roots }\end{array}$} & \multicolumn{2}{|c|}{$\begin{array}{c}\text { Root } \\
\text { weight }\end{array}$} & \multicolumn{2}{|c|}{$\begin{array}{l}\text { Plant } \\
\text { height }\end{array}$} & \multicolumn{2}{|c|}{$\begin{array}{c}\text { Percentage } \\
\text { of infected } \\
\text { sheaths }\end{array}$} & \multicolumn{2}{|c|}{$\begin{array}{l}\text { Degree of } \\
\text { leaf sheaths } \\
\text { infection }\end{array}$} \\
\hline & Almari & Eta & Almari & Eta & Almari & Eta & Almari & Eta & Almari & Eta & Almari & Eta & Almari & Eta \\
\hline R39 & 25.3 & 37.5 & 2.2 & 2.3 & 36.4 & 52.6 & 4.6 & 2.7 & 17.9 & 21.5 & 20.0 & 42.0 & 2.2 & 3.0 \\
\hline R40 & 5.0 & 2.5 & 0.6 & 0.3 & 15.4 & 42.5 & 4.4 & 2.7 & 16.7 & 21.5 & 7.3 & 16.6 & 0.9 & 1.0 \\
\hline R45 & 2.5 & 12.5 & 0.8 & 1.1 & 13.7 & 37.7 & 4.3 & 3.2 & 14.9 & 19.4 & 6.7 & 28.0 & 1.0 & 1.7 \\
\hline R47 & 10.0 & 10.0 & 1.5 & 2.0 & 21.6 & 31.9 & 3.5 & 2.9 & 15.9 & 20.0 & 30.0 & 34.7 & 2.3 & 1.8 \\
\hline R59 & 32.5 & 42.5 & 2.7 & 2.9 & 38.5 & 82.3 & 4.5 & 3.1 & 16.9 & 23.9 & 20.0 & 42.0 & 1.0 & 2.1 \\
\hline R42 & 0.0 & 0.0 & 0.0 & 0.0 & 21.9 & 25.5 & 4.7 & 3.0 & 16.4 & 23.4 & 11.3 & 23.3 & 1.0 & 1.2 \\
\hline R1 & 32.5 & 82.5 & 1.8 & 2.5 & 35.1 & 39.9 & 5.7 & 2.9 & 16.8 & 21.3 & 10.7 & 25.3 & 1.1 & 0.8 \\
\hline R8 & 15.0 & 7.5 & 0.9 & 0.6 & 17.8 & 31.2 & 4.7 & 2.9 & 16.5 & 20.7 & 6.7 & 24.0 & 0.4 & 1.1 \\
\hline R11 & 22.5 & 25.0 & 1.9 & 2.2 & 22.8 & 51.1 & 7.1 & 3.4 & 18.1 & 22.6 & 13.3 & 27.3 & 1.1 & 2.6 \\
\hline R24 & 7.5 & 17.5 & 1.8 & 2.5 & 10.1 & 32.1 & 4.9 & 3.3 & 17.0 & 22.9 & 0.0 & 25.3 & 0.0 & 1.6 \\
\hline R29 & 7.5 & 10.0 & 1.5 & 1.8 & 17.7 & 53.6 & 5.0 & 3.3 & 17.1 & 22.6 & 6.7 & 16.7 & 0.8 & 1.1 \\
\hline
\end{tabular}


Table 2

The mean squares from analysis of variance for features assessed in laboratory experiment

\begin{tabular}{|l|c|c|c|c|c|c|c|}
\hline \multirow{2}{*}{$\begin{array}{l}\text { Source of } \\
\text { variation }\end{array}$} & \multirow{2}{*}{$\begin{array}{c}\text { Number of } \\
\text { degrees of } \\
\text { freedom }\end{array}$} & \multicolumn{2}{|c|}{$\begin{array}{c}\text { Percentage of } \\
\text { infected stems }\end{array}$} & \multicolumn{2}{|c|}{ Degree of stem infection } & \multicolumn{2}{|c|}{$\begin{array}{c}\text { Percentage of } \\
\text { infected roots }\end{array}$} \\
\cline { 3 - 9 } & 10 & $556.4 * *$ & $232.0 * * *$ & $2.42^{*}$ & $3.84 * * *$ & 373.7 & $1014.5^{* * *}$ \\
\hline Isolates & 33 & 149.0 & 158.3 & 0.90 & 0.66 & 176.2 & 167.0 \\
\hline Residual & 33 & ETA & Almari & ETA & Almari & ETA \\
\hline
\end{tabular}

* significant at $\alpha=005$

$* *$ significant at $\alpha=001$

*** significant at $\alpha=0001$

Table 3

The mean squares from analysis of variance for features assessed in greenhouse experiment

\begin{tabular}{|c|c|c|c|c|c|c|c|c|c|}
\hline \multirow[t]{2}{*}{$\begin{array}{l}\text { Source of } \\
\text { variation }\end{array}$} & \multirow{2}{*}{$\begin{array}{l}\text { Number of } \\
\text { degrees of } \\
\text { freedom }\end{array}$} & \multicolumn{2}{|c|}{$\begin{array}{l}\text { Weight of } \\
\text { roots }(\mathrm{g})\end{array}$} & \multicolumn{2}{|c|}{$\begin{array}{l}\text { Growth of } \\
\text { plants }(\mathrm{cm})\end{array}$} & \multicolumn{2}{|c|}{$\begin{array}{c}\text { Percentage of } \\
\text { infected leaf } \\
\text { sheaths }\end{array}$} & \multicolumn{2}{|c|}{$\begin{array}{c}\text { Degree of leaf } \\
\text { sheaths infection }\end{array}$} \\
\hline & & Almari & ETA & Almari & ETA & Almari & ETA & Almari & ETA \\
\hline Isolates & 10 & $4.17 * * *$ & 0.32 & 3.77 & 10.10 & 352.9 & 373.3 & 2.25 & 2.46 \\
\hline Residual & 44 & 0.78 & 0.37 & 1.89 & 7.26 & 22.4 & 544.5 & 1.61 & 1.31 \\
\hline
\end{tabular}

*** significant at $\alpha=0001$

Table 4.

Correlation coefficients of features examined

\begin{tabular}{|c|c|c|c|c|c|c|c|}
\hline \multirow{2}{*}{$\begin{array}{l}\text { Degree of stem } \\
\text { infected }\end{array}$} & Almari & $0.81 * *$ & & & & & \\
\hline & Eta & $0.68 *$ & & & & & \\
\hline \multirow{2}{*}{$\begin{array}{l}\text { Percentage of } \\
\text { infected roots }\end{array}$} & Almari & $0.85^{* *}$ & $0.61 *$ & & & & \\
\hline & Eta & 0.38 & 0.57 & & & & \\
\hline \multirow{2}{*}{ Root weight } & Almari & 0.39 & 0.26 & 0.12 & & & \\
\hline & Eta & -0.15 & 0.25 & 0.11 & & & \\
\hline \multirow{2}{*}{ Plant height } & Almari & 0.52 & 0.55 & 0.40 & $0.63 *$ & & \\
\hline & Eta & 0.09 & 0.20 & 0.45 & 0.32 & & \\
\hline \multirow{2}{*}{$\begin{array}{l}\text { Percentage of } \\
\text { infected sheaths }\end{array}$} & Almari & 0.38 & 0.37 & 0.60 & -0.29 & 0.05 & \\
\hline & Eta & 0.38 & 0.60 & 0.48 & -0.20 & 0.03 & \\
\hline \multirow{3}{*}{$\begin{array}{l}\text { Degree of sheaths } \\
\text { infection }\end{array}$} & Almari & 0.24 & 0.23 & 0.52 & -0.26 & 0.06 & $0.88 * *$ \\
\hline & Eta & 0.10 & 0.50 & 0.45 & 0.09 & 0.10 & $0.76^{* *}$ \\
\hline & & $\begin{array}{l}\text { Percentage } \\
\text { of infected } \\
\text { stems }\end{array}$ & $\begin{array}{l}\text { Degree } \\
\text { of stem } \\
\text { infected }\end{array}$ & $\begin{array}{l}\text { Percentage } \\
\text { of infected } \\
\text { roots }\end{array}$ & $\begin{array}{l}\text { Root } \\
\text { weight }\end{array}$ & $\begin{array}{l}\text { Plant } \\
\text { height }\end{array}$ & $\begin{array}{l}\text { Percentage } \\
\text { of infected } \\
\text { leaf sheaths }\end{array}$ \\
\hline
\end{tabular}

* significant at level $\alpha=005$

** significant at level $\alpha=001$ 


\section{Genetic variability}

Genetic variability between 11 isolates of $R$. cerealis was determined using the data generated by seven RAPD primers. Only reproducible bands and of sufficient intensity were scored. The number of polymorphic fragments varied from 3 to 7 per primer (Figure 2). Thirty-three polymorphic RAPD markers were obtained (Table 5). The size of PCR products ranged from 0.2 to $3.1 \mathrm{~kb}$.

Table 5

Code and sequence of primers tested with polymorphic RAPD markers number

\begin{tabular}{|l|c|c|}
\hline Primer code & Sequence 5' to 3' & Polymorphic band number \\
\hline C1503 & CGGCCCACGT & 4 \\
\hline C1504 & ACGGCGTCAC & 3 \\
\hline OPC-05 & GATGACCGCC & 5 \\
\hline OPJ-04 & CCGAACACGG & 4 \\
\hline OPJ-05 & CTCCATGGGG & 7 \\
\hline OPJ-14 & CACCCGGATG & 4 \\
\hline OPJ-18 & TGGTCGCAGA & 6 \\
\hline & Total & 33 \\
\hline
\end{tabular}
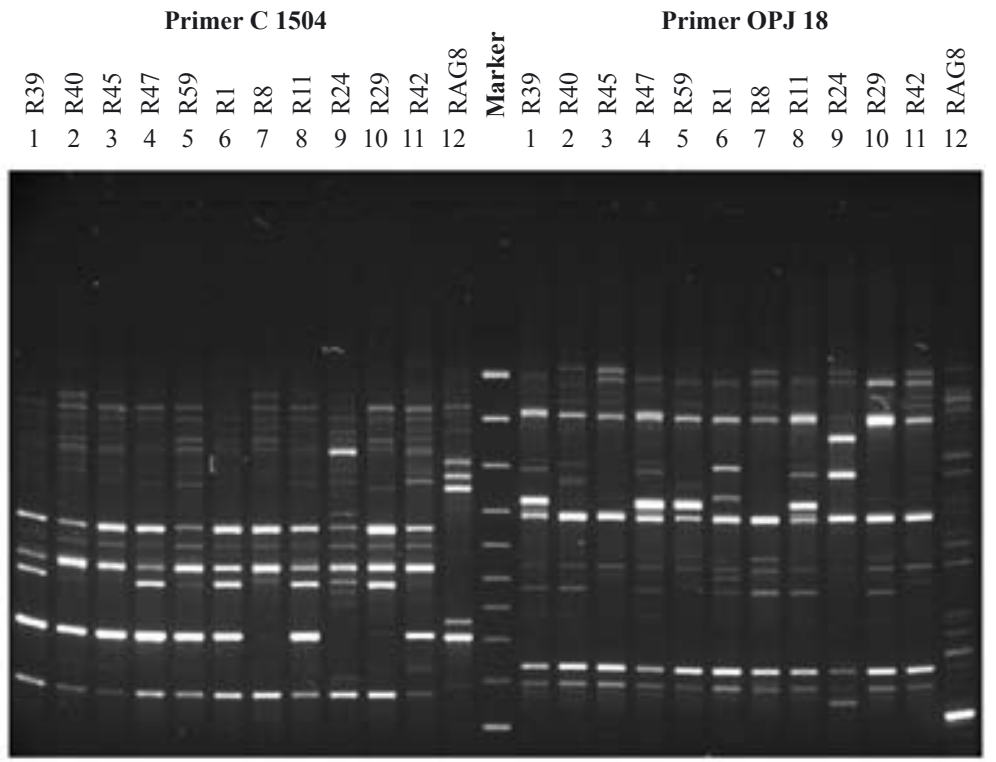

Figure 2. RAPD-PCR patterns of Rhizoctonia spp. isolates amplified with primer C1504 and OPJ18. Lines1-11 $R$. cerealis and line 12 reference isolate $R$. solani AG8. A Gene Ruler ${ }^{\mathrm{TM}} 100 \mathrm{bp}$ DNA Ladder Plus (Fermentas) was used as a molecular size standard for RAPD markers (M) 
The comparison of each profile for each primer was done on the basis of the presence (1) versus absence (0) of RAPD products of the same length. Genetic similarity was estimated according to the formula given by $\mathrm{Ne} \mathrm{i}$ and Li (1979). The lowest genetic similarity was found for isolates R24 and R59, R11 and R8 (equal 0.2). The most similar isolates on molecular level were R47 and R39 (equal 1.0). The relationship among isolates was presented in the form of a dendrogram (Figure 3). Clustering analysis resolved two groups at the $36 \%$ similarity level. Correlation coefficient between phenotypic similarity and genetic similarity was equal 0.28 and statistically significant at the level of $\alpha$ equal 0.05 (number of degrees of freedom equal 53).

Moreover, the association between molecular markers and phenotypic features was estimated using analysis of regression. Five molecular markers were correlated with each feature examined on Almari (Table 6) and from 2 to 6 markers on Eta (Table 7). The percentage variation accounted by marker ranged from $30.5 \%$ for OPJ05d marker associated with percentage of infected stems of Almari to $72.3 \%$ for OPJ05c marker associated with degree of stem infection of Eta.

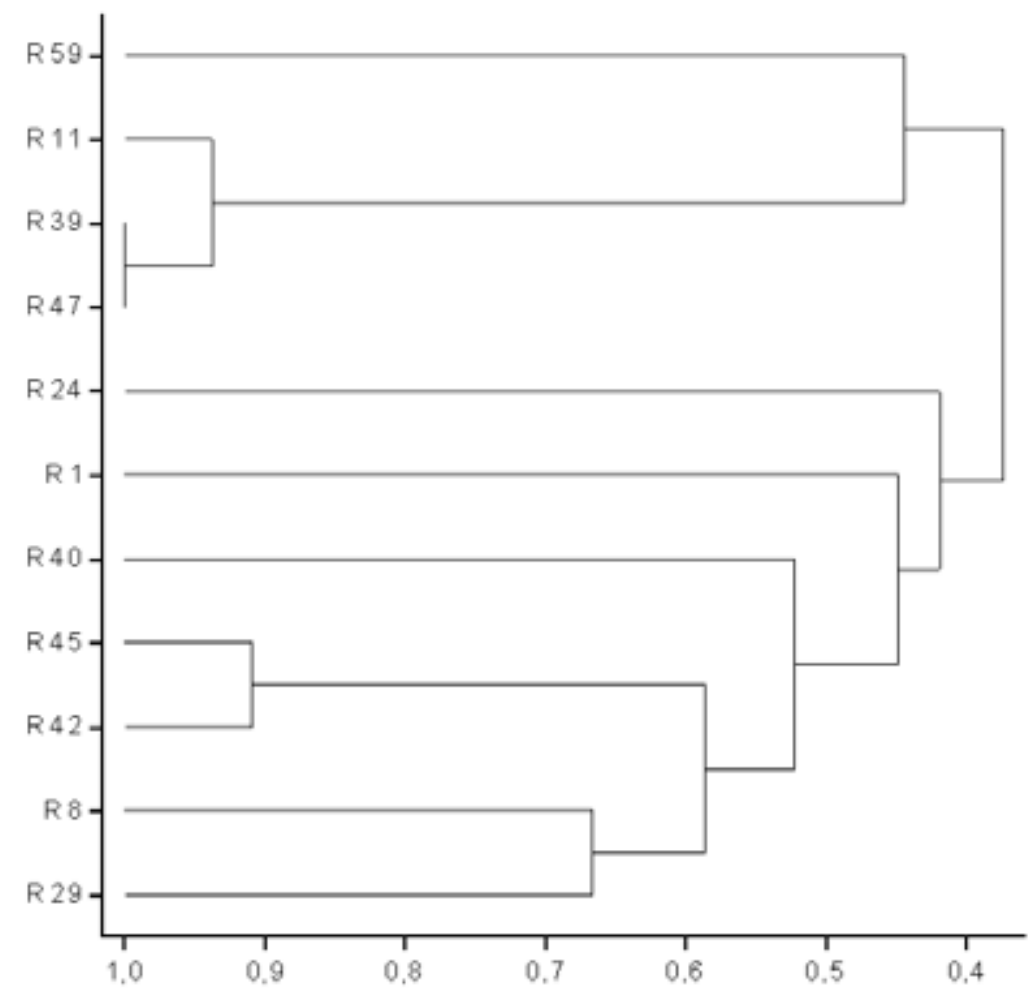

Figure 3. Phylogenetic analysis of Rhizoctonia cerealis isolates. Genetic distances were obtained by RAPD-PCR analysis with seven 10-mer primers 
Table 6

Markers associated with features examined on the Almari cultivar

\begin{tabular}{|c|c|c|c|c|}
\hline Marker code & $\begin{array}{c}\text { Estimates of } \\
\text { regression } \\
\text { coefficients }\end{array}$ & p-value & $\begin{array}{c}\text { Percentage } \\
\text { variation } \\
\text { accounted }\end{array}$ & $\begin{array}{c}\text { Observation's } \\
\text { standard error }\end{array}$ \\
\hline \multicolumn{5}{|c|}{ percentage of infected stems } \\
\hline OPJ05c & -15.71 & 0.017 & 42.7 & 8.93 \\
\hline OPJ05d & 15.45 & 0.045 & 30.5 & 9.83 \\
\hline OPJ05h & -15.71 & 0.017 & 42.7 & 8.93 \\
\hline OPC05b & -21.91 & 0.008 & 51.7 & 8.20 \\
\hline OPJ18a & -15.71 & 0.017 & 42.7 & 8.93 \\
\hline & & degree of stem infection & 0.56 \\
\hline OPJ04b & 1.09 & 0.011 & 47.9 & 0.48 \\
\hline OPJ05c & -1.22 & 0.002 & 62.8 & 0.54 \\
\hline OPJ05h & -1.12 & 0.007 & 52.0 & 0.54 \\
\hline OPJ18a & -1.12 & 0.007 & 52.0 & 0.61 \\
\hline OPJ18d & 1.04 & 0.024 & 38.9 & \\
\hline & & \multicolumn{5}{|c|}{} \\
\hline
\end{tabular}

Table 7

Markers associated with features examined on the ETA cultivar

\begin{tabular}{|c|c|c|c|c|}
\hline $\begin{array}{c}\text { Marker } \\
\text { symbol }\end{array}$ & $\begin{array}{c}\text { Estimates of } \\
\text { regression } \\
\text { coefficients }\end{array}$ & p-value & $\begin{array}{c}\text { Percentage } \\
\text { variation } \\
\text { accounted }\end{array}$ & $\begin{array}{c}\text { Standard error of } \\
\text { observations }\end{array}$ \\
\hline \multicolumn{5}{|c|}{ percentage of infected stems } \\
\hline OPJ05c & -29.30 & 0.035 & 33.8 & 19.6 \\
\hline OPC05b & -48.90 & 0.002 & 63.8 & 14.5 \\
\hline \multicolumn{5}{|c|}{ degree of stem infection } \\
\hline OPJ04b & 1.33 & 0.015 & 44.5 & 0.73 \\
\hline OPJ05c & -1.63 & $<0.001$ & 72.3 & 0.52 \\
\hline OPJ05h & -1.37 & 0.011 & 48.0 & 0.71 \\
\hline OPC05c & -1.47 & 0.048 & 29.6 & 0.82 \\
\hline C1504a & -1.47 & 0.048 & 29.6 & 0.82 \\
\hline OPJ18a & -1.37 & 0.011 & 48.0 & 0.71 \\
\hline
\end{tabular}




\section{DISCUSSION}

For molecular identification purposes a molecular analysis was carried out. ITS sequences of 11 isolates examined were most similar to that of $R$. cerealis found in Genbank. ITS size polymorphism and sequencing analysis allowed also to discriminate between $R$. cerealis and reference isolate representing $R$. solani AG8. In the case of $R$. cerealis best matching sequence from database differs in three nucleotides (similarity $99.5 \%$ ). In most isolates examined more than one sequence was found what is consisted with binucleate nature of $R$. cerealis hypha cells. Isolate AG8 representing $R$. solani possessed two sequences of ITS region. In this case best matching sequence from database differed in one and two nucleotides, respectively. Cells of $R$. solani are multinucleate. The number of nuclei is lower in older cells, probably due to the formation of secondary septa (S neh et al., 1991). At the species level the noncoding internal transcribed spacers (ITS) are often used for phylogeny studies, as they usually vary between species within a genus (Cooke and D uncan, 1997). Sequences of rDNA in fungi are conserved and contain components reflecting different evolutionary rates that are phylogenetically and taxonomically informative (B r u n s et al., 1991). Furthermore, the variation observed in the length of PCR fragments of the rDNA ITS region was not random and could be used as grouping characteristics (Pasqual et al., 2000).

All Rhizoctonia spp. isolates under investigation caused typical sharp eyespot lesions on the base of stems of wheat seedlings. The isolates R1, R29, R39 and R54 were the most pathogenic towards wheat. Percentage of infected stems ranged from 25.3 to 82.5 and roots from 35 to 82.3. L i p p s and Her r (1982) also carried out an experiment with isolates assigned to $R$. cerealis. Three of the examined isolates have caused typical sharp eyespot lesions on the base of wheat culms. The rating for CAG1 (Ceratobasidium anasthomosis group) tester isolate ( $R$. cerealis) was 4.0 on a scale on which 0 means no symptoms and 5 means lesion with penetration to the center of culm or dead plant. The nonpathogenic isolates have induced only slight browning on leaf sheaths. None of the 28 wheat isolates caused visible root rot, root stunting or reduction of seedlings top growth. S te r n and J o n e s (1978) reported that nine of ten isolates obtained from wheat culm anasthomosed with an AG4 tester isolate of $R$. solani. Pathogenicity trials proved that $R$. solani AG4 isolates caused eyespot on wheat plants grown in the greenhouse. These results obtained in experiment with $R$. solani and on the other hand results presented by Lipps and Her r (1982) and other researchers (P i t t, 1964; Van der H o e v e n et al., 1980) for $R$. cerealis indicate that two different species can cause sharp eyespot lesions on cereals.

In this experiment the Almari cultivar turned out to be more susceptible to infection with $R$. cerealis than Eta. According to expectation, degree of stem infection and percentage of infected stems were correlated for both cultivars examined. Similarly, the percentage of infected sheaths was correlated with degree of sheaths infection. On the other hand, the percentage of infected roots was correlated with percentage of infected stems as well as degree of stem infection for the Almari cultivar. Also only for Almari, the significant correlation between plant height and root weight was calculated. 
To estimate genetic variability of isolates examined molecular analysis was carried out. The obtained results show, that RAPD has provided a suitable tool for distinguishing species and detecting intraspecies polymorphism (W i 11 i a m s et al., 1990). Nicholson and Parry (1996) had used RAPD markers to differentiate causal agents of stem base complex of cereal diseases. RAPDs easily separated two species, which were difficult to distinguish on the morphological grounds. Our research revealed that examined isolates of. $R$. cerealis exhibit a high level of genetic variation. This confirms the significant intraspecies variability of $R$. cerealis that has been demonstrated by Nicholson and Parry (1996).

The dendrogram was prepared using the unweighted pair group method of arithmetic means (UPGMA), which had been used previously with different fungi ( $\mathrm{P}$ e 1 to $\mathrm{n}$ e $\mathrm{n}$ et al., 1996; S un et al., 2003). Cluster analysis of RAPD data resolved the isolates into two main groups. Knowledge of the genetic structure of pathogen population has important implications for plant breeding. It is worth pointing out that pathogen population with a large amount of genetic variation is capable of rapidly evolving responses to changing environmental conditions (McDonald et al., 1994). Moreover, as many as 18 molecular markers were associated with pathogenicity of $R$. cerealis isolates. In the case of the Almari variety ten markers associated with percentage of infected stems and degree of stem infection were found, and three of them (OPJ05c, OPJ05h, OPJ18a) were joint for both features. Considering negative regression coefficient values the data indicate that isolates with these marker bands are less pathogenic, that make them useful in preliminary selection. The studies carried out on the Eta variety are also interesting. For almost all molecular markers associated with percentage of infected stems and degree of stem infection (7 of 8) a negative value of estimator was calculated. It means that it can be possible to use these markers to discriminate between more and less pathogenic isolates. Unfortunately, no any marker associated with percentage of infected roots was found, although isolates differed as regards that feature.

The obtained results are preliminary characteristics of the $R$. cerealis and more extensive studies are necessary to get to know the pathogen at molecular level and to estimate genetic variability of them in-depth.

\section{REFERENCES}

Altschul S. F., Thomas L. M., Schaffer A. A., Jinghui Z., Zheng Z., We b b M. and Li p m a n D. J., 1997. Gapped BLAST and PSI-BLAST: a new generation of protein database search programs. Nucl. Acids Res., 25: 3389-3402.

Augustin C., Ulrich K., Ward E. and Werner A., 1999. RAPD-Based Inter- and Intravarietal Classification of Fungi of the Gaeumannomyces-Phialophora Complex. J. Phytopathology, 147: 109-117.

Balesdent M. H., Jedryczka M., Jain L., Mendes-Pereira E., Bertrandy J . and R o u x e 1 T., 1998. Conidia as a substrate for internal transcribed spacer-based 
PCR identification of members of Leptosphaeria maculans species complex. Phytopathology, 88(11): 1210-1217.

Bruns T. D., White T. J. and Taylor J. W., 1991. Fungal molecular systematics. Ann. Rev. Ecol. Syst., 22: 525-564.

Caliński T., 1970. Wielozmienna analiza wariancji i pokrewne metody wielowymiarowe.(Multivariate analysis of variance and other multivariate methods) Materiały Kursu Szkoleniowego PTB i Wydziału V PAN, Warszawa.

Cooke D. E. L. and D un c a n J. .M., 1997. Phylogenetic analysis of Phytophthora species based on ITS1 and ITS 2 sequences of the ribosomal RNA gene repeat. Mycol. Res., 101 (6): 667-677.

Cooke D. E. L., Kennedy D. M., Guy D. C., Russel1 J., Unkles S. E. and D un c an J. M., 1996. Relatedness of Group I species of Phytophthora as assessed by randomly amplified polymorphic DNA (RAPDs) and sequences of ribosomal DNA. Mycol. Res., 100 (3): 297-303.

Crawford A. R., Bassam B. J., Drenth A., Maclean D. J. and Irwin J. A. G., 1996. Evolutionary relationships among Phytophthora species deduced from $r$ DNA sequence analysis. Mycol. Res., 100(4): 437-443.

Goodw in P. H. and A n n is S. L., 1991. Rapid identification of genetic variation and pathotype of Leptosphaeria maculans by random amplified polymorphic DNA assay. Appl. Environ. Microbiol., 57: 2482-2486.

Hollin s T. W., Je 11 is G. J. and S c ot t P. R., 1985. Sharp eyespot of cereals and Rhizoctonia of potato. [In:] Ecology and Management of Soilborne Plant Pathogens.C. A. Parker (ed), Amer. Phytopathol. Soc., St. Paul, pp. 34-35.

Irzykowski W., Sun J., Li Q., Gao T., Hou S., Águedo A., Jędryczka M., 2004. DNA polymorphism in Sclerotinia sclerotiorum isolates from oilseed rape in China. IOBC Bulletin, 27 (10): 67-76.

Lipps P. E. and Herr L. J., 1982. Etiology of Rhizoctonia cerealis in sharp eyespot of wheat. Phytopathology, 72: 1574-1577.

Mardia K. V., Kent J. T. and Bibby J. M., 1979. Multivariate analysis. Academic Press, London.

Mazzola M. Smiley R. W., Rovira A. D. and Cook R. J., 1996. Characterisation of Rhizoctonia isolates, disease occurrence and management in cereals. [In:] Rhizoctonia species: Taxonomy, Molecular Biology, Ecology, Pathology and Disease Control. B. Sneth (ed), Kluwer Academic Publishers, Netherlands, pp. 259-267.

Nei M. and Li W. H., 1979. Mathematical model for studying genetic variation in terms of restriction endonucleases. Proc. Acad. Sci., USA 76: 5269-5273.

Nichols on P. and Parry D. W., 1996. Development and use of a PCR assay to detect Rhizoctonia cerealis, the cause of sharp eyespot in wheat. Plant Path., 45: 872-883.

Pasqual C. B., Toda T., Raymondo A. D. and Hyakumachi M., 2000. Characterization by conventional techniques and PCR of Rhizoctonia solani isolates causing banded leaf sheath blight in maize. Plant Path., 49: 108-118.

Peltonen S., Jalli M., Kammiovirta K. and Karjalainen R., 1996. Genetic variation in Drechslera teres populations as indicated by RAPD markers. An. Appl. Biol., 128: $465-477$.

P i t t D., 1964. Studies on sharp eyespot disease of cereals. Ann. Appl. Biol., 54: 77-89. 
Sneh B., Burpee L. and Ogoshi A. 1991. Identification of Rhizoctonia species. APS Press, St. Paul, pp. 36.

Soller M., Brody T. and Genizi A., 1976. On the power of experimental designs for the detection of linkage between marker loci and quantitative loci crosses between inbred lines. Theor. Appl. Genet., 47: 35-39.

Stern R. E. and J on e s J. P., 1978. Sharp eyespot of wheat in Arkansas caused by Rhizoctonia solani. Plant Dis. Rep., 62:56-60.

S un G., B ond M., Nass H., Martin R. and D ong Z., 2003. RAPD polymorphisms in spring wheat cultivars and lines with different level of Fusarium resistance. Theor. Appl. Genet., 106: 1059-1067.

Thompson J. D., Gibs on T. J., Plewniak F., Jeanmougin F. and Higgins D. G., 1997. The ClustalX windows interface: flexible strategies for multiple sequence alignment aided by quality analysis tools. Nucl. Acids Res., 24: 4876-4882.

Van der Hoeven E. P. and B ollen G. J., 1980. Effect of benomyl on soil fungi associated with rye. I. Effect on the incidence of sharp eyespot caused by Rhizoctonia cerealis. Neth. J. Pl. Pathol., 86: 163-180.

Williams J. G. K., Kubelik A. R., Livak K.J., Rafalski J.A. and Tigney S.V., 1990. DNA polymorphisms amplified by arbitrary primers are useful as genetic markers. Nucleic Acids Res., 18: 6531-6535.

\section{Zastosowanie metod molekularnych i konwencjonalnych do identyfikacji i analizy zróżnicowania genetycznego izolatów Rhizoctonia.}

\section{Streszczenie}

W prezentowanych badaniach oceniano patogeniczność izolatów Rhizoctonia spp. w stosunku do siewek pszenicy w warunkach laboratoryjnych i szklarniowych. W obu doświadczeniach badano 7 cech: wysokość roślin, masę korzeni, procent porażonych łodyg i pochew liściowych oraz stopień porażenia łodygi i pochwy liściowej. Najbardziej patogeniczne okazały się izolaty R1, R29, R39 i R59. Procent porażonych łodyg mieścił się w zakresie od 25.3 do 82.5 , a procent porażonych korzeni od 35 do 82.3. Wykazano, że amplifikacja wewnętrznych transkrybowanych sekwencji rozdzielających (ITS1 i ITS2) geny kodujące $18 \mathrm{~S}, 5.8 \mathrm{~S}$ i $28 \mathrm{~S}$ rRNA oraz analiza sekwencyjna tych regionów wystarczyły do rozróżnienia dwóch gatunków rodzaju Rhizoctonia. Losowo amplifikowany polimorficzny DNA (RAPD) wykorzystano do oceny zróżnicowania genetycznego między izolatami. Potwierdzono użyteczność metody RAPD w różnicowaniu izolatów na poziomie wewnątrzgatunkowym. Po zastosowaniu siedmiu losowych starterów w łańcuchowej reakcji polimerazy (PCR) uzyskano 33 markery RAPD. W wyniku analizy klasterów danych uzyskanych w reakcjach RAPD wyodrębniono dwie grupy izolatów $R$. cerealis na poziomie podobieństwa równym $36 \%$. Ponadto, znaleziono istotne związki pomiędzy markerami molekularnymi a patogenicznością izolatów $R$. cerealis. 